\title{
Causal Relationships among Dimensions of Consumer-Based Brand Equity and Purchase Intention: Fashion Industry
}

\author{
Nasreen Khan ${ }^{1}$, Syed Hamed Razavi Rahmani ${ }^{1}$, Hong Yong Hoe ${ }^{1} \&$ Tan Booi Chen ${ }^{1}$ \\ ${ }^{1}$ Department of Marketing, Faculty of Management, Multimedia University, Malaysia \\ Correspondence: Nasreen Khan, Department of Marketing, Faculty of Management, Multimedia University, \\ Malaysia. E-mail: nasreenkhan88@yahoo.com
}

Received: October 9, 2014

Accepted: November 14, 2014

Online Published: December 20, 2014

doi:10.5539/ijbm.v10n1p172

URL: http://dx.doi.org/10.5539/ijbm.v10n1p172

\begin{abstract}
Due to the intense competition in market place, customers nowadays are exposed to several brands from across the globe. Building the brand equity becomes an important source of differentiation. It is widely recognized the important role of brand image in establishing brand awareness and brand attitude. Numbers of research are still debating on relationship among the dimensions of brand equity and yet no conclusive decision has been made. The purpose of the research is to investigate the relationship among the dimensions of brand equity and propose a model that predicts the purchase intention in fashion industry. The result confirms the casual relationship among the dimensions of brand equity. Interestingly perceived quality rather than brand image has stronger impact on brand loyalty and brand loyalty rather than perceived quality has stronger impact on purchase intention. This study contributes the original model of customer based brand equity of Aaker by introducing brand image as one of the assets to measure the brand equity concept. Strategic guidelines are provided to managers in building the brand loyalty.
\end{abstract}

Keywords: brand awareness, brand image, brand loyalty, perceived quality, purchase intention, fashion industry

\section{Introduction}

The influence of globalization and intensive efforts from media advertising makes several foreign brands popular in Asia countries (Chada \& Husband, 2006). The existence of different fashion clothing brands from West to Asia is considerable topic in marketing. Having a well known brand image could assist the brand to create an uniqueness in marketplace (Aaker, 1996), encourage greater intermediary co-operation, increase the chance for further brand extension and also increase the profit margins, (Delgado-Ballester \& Munuera-Aleman, 2005). Consumers nowadays are well informed and knowledgeable with more choices. It is crucial for the firms to differentiate their product in terms of brand equity (Bennett \& Rundle-Thiele, 2005). According to Aaker (1991), original model of customer based brand equity involved five dimensions-brand awareness, brand associations, brand loyalty, perceived quality, and other proprietary assets. Later, Keller (1993) evaluates the brand equity in terms of two dimensions-brand awareness and brand image.

In order to build brand equity, brand image as well as brand awareness should be an important aim of marketing program of a firm. Delong et al. (2004) consider that if the consumers have knowledge about the brand, they appear to recognize the brand. In this way, managing brand image and its awareness is a great importance. It is generally approved that brand attitude and brand image are formed due to brand awareness. Only with brand awareness, consumers are likely to acquire the product. As such, brand awareness is an important factor to determine purchase intention (Macdonald \& Sharp, 2000).

However, there is very limited research that considers brand awareness and brand image as combination affect on purchase intention (Lin et al., 2006). Numbers of literature have proved that perceived quality and brand awareness as pre requisite and brand loyalty as the guarantee to purchase the product (Oliver, 1997). There is still no comprehensive research has yet to investigate the relationship among the dimensions of brand equity. Therefore, the purpose of the research is to investigate the casual relationship among dimensions of brand equity (brand awareness, brand image, perceived quality, and brand loyalty) and purchase intention of consumers in the context of Malaysia fashion clothing industry. 


\section{Literature Review}

A basic idea of brand equity is that the power of a brand lies in the minds of consumers and what they have experienced and learned about the brand over time. Brand equity provides value for both the customer and the firm (Bagozzi et al., 1998). Brand equity is defined as a set of assets and liabilities linked to the brand, which add value to or subtract value from a product in its relationship with customers (Aaker, 1991). Aaker discovered that the value of brand equity results from five brand equity assets; brand loyalty, brand awareness, perceived quality, brand associations, and other proprietary brand assets. Whereas, Keller (1993) revealed brand equity as the differential effect of brand knowledge on consumer response to the marketing of the brand and measure the brand equity based on two assets; brand awareness and brand image. Keller highlighted the importance of consumer brand knowledge which is descriptive and evaluative information about brand, and recorded in consumer memory (Keller, 2003). He further criticized that consumers are able to recognize and recall the brand image only if they are aware of the brand existence and have knowledge about the brand (Keller, 1998). As such, addressing the brand awareness alone does not explain on consumer's familiarly with the brand (Das et al., 2012). Hence brand awareness and brand image together create the brand knowledge. There is a lack of research on brand dimensions in fashion clothing context. This study proposes brand equity dimensions in fashion clothing as brand awareness, brand image, brand loyalty and perceived quality.

\subsection{Brand Awareness}

Brand awareness enables consumers to recognize a brand from different product category (Heding, Knudtzen \& Bjerre, 2009) and assist consumers in making decision to purchase (Percy \& Rossiter, 1992). Product with higher brand awareness will have a better quality assessment (Wang \& Hwang, 2001) and higher market share (Lin, 2006). On the other hand, some researchers have argued that brand awareness has a significant effect on purchase intention (Macdonald \& Sharp, 2000). Others have supported that knowledgeable consumers have high chances of being loyal (Parasuraman \& Grewal, 2000 and Wu, 2007). Consequently, following hypothesis is proposed.

H1. Brand awareness has a significant impact on perceived quality.

H2. Brand awareness has a significant impact on brand loyalty.

H3. Brand awareness has a significant impact on purchase intention

\subsection{Brand Image}

Brand image is described as consumers' perceptions and beliefs about the particular brand (Kotler \& Keller, 2009). Through the uniqueness of brand image, consumers are able to evaluate the quality, recognize a product, reduce purchase risks, and attain the satisfaction. According to Grewal et al. (1998), when a product has strong brand image, consumers recognize it's with high quality. Similarly Rao and Monroe (1989) conclude that most of the time consumers use brand image as short-hand of quality and value expression. Several scholars claim that those brands with image are more likely to have more loyal consumers (Bennett \& Rundle-Thiele, 2005). Aaker and Keller (1990) further elaborate that consumer with stronger brand image lead to develop intention to purchase. Since there is no conformity on effect of the brand image, the following hypotheses are developed.

H4. Brand Image has a significant impact on perceived quality.

H5: Brand image has significant impact on brand loyalty.

H6. Brand Image has a significant impact on purchase intention.

\subsection{Perceived Quality}

Perceived quality is consumer judgment on added value of a product (Bhuian, 1997). Consumer evaluates product quality based on his/her previous experiences and feelings (Zeithaml, 1988). Some of these quality characteristics are innate, while others are assigned to the products. Since some quality characteristics are difficult to detect directly, other cues such as brand image and brand names become important in evaluating quality. Studies have reported that perceived quality will influence the trust and satisfaction with the brand, which in turn leads to develop brand loyalty. In addition Yee and Sidek (2008) concludes that the product quality is the most important factor that contributes to brand loyalty. However, Jones et al. (2002) argue that there is a positive relationship between perceived quality and purchase intention. Therefore, the following hypotheses are formulated.

H7. Perceived Quality has a significant impact on brand loyalty.

H8. Perceived Quality has a significant impact on purchase intention. 


\subsection{Brand Loyalty}

Brand loyalty is the attitudes of consumer toward a brand preference of a product (Deighton et al., 1994). Brand loyal consumes do not evaluate the brand; they just make a purchase confidently (Sidek at al., 2008). Thus, it represents a repurchase commitment of potential consumers and most likely they will not switch to another brand (Oliver, 1999). Therefore, the following hypotheses are developed.

H9. Brand Loyalty has a significant impact on purchase Intention

\subsection{Consumer Purchase Intention}

Many people do consume different kinds of products every day, from basic needs to high-valued collectables. When consumers identify the needs of having a product, they start with searching the information about the product, then evaluate the alternatives of brand available, and finally make decision to purchase (Engel, Blackwell and Miniard, 1995). Purchase intention means a consumer has personal preference towards a certain product, and it has proven to be a significant factor to predict consumer behavior (Fishbein \& Ajzen, 1975). Purchase intention measure the possibility of a consumer to buy a product, and the higher the purchase intention is, the higher a consumer's willingness is to buy a product (Schiffman \& Kanuk, 2000). According to Kimery \& McCord (2000), measuring consumer purchasing behavior is difficult and as such it is often predicted by purchase intention. Thus, Zeithaml (1988) recommend intended to buy, possible to buy and considered to buy as measurement items to purchase intention.

\section{Conceptual Framework}

Brand equity has been known as a valuable source of competitive advantage. It results from the consumer's perception of overall superiority of a particular product (Belch \& Belch, 2009). It measures everything that exists in the minds of customers with respect to a brand (Keller and Donald, 2003). Such measures of consumer-based brand equity have received substantial attention in both academia as well as industry. One of the most widely used models today is customer-based brand equity model by Keller (1993). Keller proposes brand knowledge as fundamental brand equity and explains brand knowledge in terms of brand awareness and brand image. Where as Aaker (1996) also proposes an brand equity model which contains five mindset measures: brand awareness, perceived quality, brand loyalty, brand associations and other proprietary assets such as patents, trademarks and channel relationships. These two models are frequently and separately used to apply in marketing and consumer behavior research (Kim, et al., 2008 \& Yasin, et al., 2007).

Although these two models are widely recognized, there is still no conformity on dimensions to measure the brand equity. Up to the author knowledge, there is no research that considers both brand awareness and brand image as measures to brand equity. As such, this research proposes four dimensions that measure the brand equity. These are brand image, brand awareness, perceived quality and brand loyalty. While brand awareness and brand image are the most significant factors that contribute to purchase intention (Macdonald \& Sharp, 2000), perceived quality is also the essential element and brand loyalty is guarantee of purchase and repurchase (Oliver, 1997). The model illustrated in figure 1 provides conceptual framework for this research. 


\section{DIMENSIONS OF BRAND EQUITY}

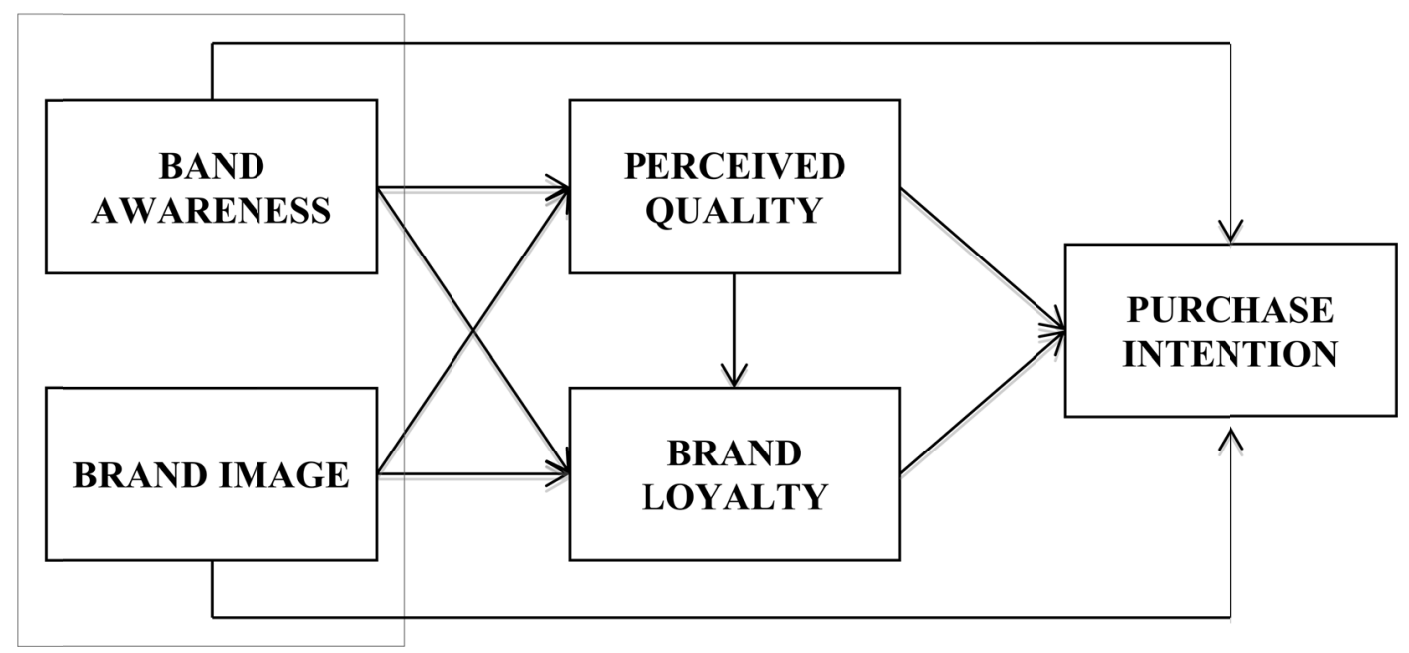

Figure 1. Conceptual framework

\section{Methodology}

The target respondents of this study are the young shoppers between the ages of 18 and 40 as young generations comprises the major consumers for fashion clothing brands (Dickson et al., 2004). Four fashion clothing brands (PADINI, ZARA, CALVIN KLEIN, and GUCCI) were selected as stimuli brand for the study. Convenience sampling method is used to collect the data and 190 returned questionnaires are used for data analysis.

The survey questionnaire consisted of 24 items to measure the dimensions of brand equity and 3 items to measure the purchase intention. Four dimensions of brand equity are brand awareness, brand image, perceived quality and brand loyalty. For the first dimension of brand equity, the items to measure the brand awareness are adapted from Yoo et al. (2000) and Aaker (1991). Items to measure the brand image are adapted from Kaplan (2007) and items to measure the perceived quality and brand loyalty are adapted from Aaker (1991), Lassar et al. (1995) and Yoo et al. (2000). Finally items to measure the purchase intention is adapted from Zeithaml (1998), and Soureli et al. (2008). All the items were developed by using five-point Likert scale $(1=$ strongly disagree to $5=$ strongly agree).

Among the analyzed samples, descriptive analysis shows that $58 \%$ of the respondents were female and $42 \%$ are male. Out of 190 respondents, $51 \%$ were Malay, $22 \%$ are Chinese, $13 \%$ are Indian and the rest are from other races. $48 \%$ of the respondents hold Bachelor degree and $30 \%$ of the respondents belong to the income range of RM 3001 to RM 4000 per month.

\section{Results}

Before conducting factor analysis, there must be a strong conceptual foundation to support the assumption that a structure does exist before the factor analysis is performed. The KMO ranges from 0.5 to 1.0 indicate factor analysis is appropriate. The result indicates that KMO value of 0.860 and Bartlett's statistics is significant and therefore it seems that factor analysis is appropriate for this data set.

The proposed brand equity dimensions consist of four factors which are measured by 24 items. The result from factors analysis confirms that brand dimensions split into 4 factors and these are brand awareness, brand image, brand loyalty, and perceived quality. The study used Cronbach's $\alpha$ to measure the internal reliability of the construct. The results show that Cronbach's $\alpha$ of brand image is 0.81 , brand awareness is 0.83 , perceived quality is 0.78 , brand loyalty is 0.80 and purchase intention is 0.81 . As the alpha value for all variables is more than 0.7 , it shows the internal consistency. Table 1 shows the data on the factor analysis.

The Bivariate Correlation analysis was performed to ensure that the independent variables used are greatly correlated to the dependent variable of this study. Examination of the correlation of the variables, brand awareness was found to be significantly correlated to perceived quality $(\mathrm{r}=.438, \mathrm{p}<0.05)$, brand loyalty $(\mathrm{r}=.348$, $\mathrm{p}<0.05)$ and purchase intention $(\mathrm{r}=.285, \mathrm{p}<0.05)$. Whereas brand image was found to significantly correlated to 
perceived quality $(\mathrm{r}=.591, \mathrm{p}<0.05)$, brand loyalty $(\mathrm{r}=.515, \mathrm{p}<0.05)$, purchase intention $(\mathrm{r}=.359, \mathrm{p}<0.05)$. Perceived quality was found to significantly correlated to brand loyalty $(\mathrm{r}=.535, \mathrm{p}<0.05)$ and purchase intention $(\mathrm{r}=.375, \mathrm{p}<0.05)$. Finally Brand loyalty was found to be significantly correlated to purchase intention $(\mathrm{r}=.520$, $\mathrm{p}<0.05)$. Table 2 shows the data on the correlation analysis.

Table 1. Factor analysis

\begin{tabular}{|c|c|c|c|c|c|}
\hline Items & 1 & 2 & 3 & 4 & Cronbach Alpha \\
\hline BA1 & 0.668 & & & & 0.83 \\
\hline BA2 & 0.567 & & & & \\
\hline BA 3 & 0.606 & & & & \\
\hline BA 4 & 0.610 & & & & \\
\hline BA 5 & 0.753 & & & & \\
\hline BI1 & & 0.623 & & & 0.81 \\
\hline $\mathrm{BI} 2$ & & 0.444 & & & \\
\hline BI 3 & & 0.516 & & & \\
\hline BI4 & & 0.730 & & & \\
\hline $\mathrm{BI} 5$ & & 0.620 & & & \\
\hline BI6 & & 0.490 & & & \\
\hline PQ1 & & & 0.741 & & 0.78 \\
\hline PQ2 & & & 0.784 & & \\
\hline PQ 3 & & & 0.586 & & \\
\hline PQ4 & & & 0.644 & & \\
\hline PQ5 & & & 0.806 & & \\
\hline PQ6 & & & 0.652 & & \\
\hline BL1 & & & & 0.637 & 0.80 \\
\hline BL2 & & & & 0.538 & \\
\hline BL 3 & & & & 0.741 & \\
\hline BL4 & & & & 0.599 & \\
\hline BL5 & & & & 0.725 & \\
\hline BL6 & & & & 0.534 & \\
\hline BL7 & & & & 0.539 & \\
\hline
\end{tabular}

Table 2. Correlation analysis

\begin{tabular}{|c|c|c|c|c|c|}
\hline Pearson correlation & Brand awareness & Brand image & Perceived quality & Brand loyalty & $\begin{array}{l}\text { Purchase } \\
\text { intention }\end{array}$ \\
\hline Brand awareness & & & $\begin{array}{l}0.438 \\
(* * *)\end{array}$ & $\begin{array}{l}0.348 \\
(* * *)\end{array}$ & $\begin{array}{l}0.285 \\
(* * *)\end{array}$ \\
\hline Brand image & & & $\begin{array}{l}0.591 \\
(* * *)\end{array}$ & $\begin{array}{l}0.515 \\
(* * *)\end{array}$ & $\begin{array}{l}0.359 \\
(* * *)\end{array}$ \\
\hline Perceived quality & & & & $\begin{array}{l}0.535 \\
(* * *)\end{array}$ & $\begin{array}{l}0.375 \\
(* * *)\end{array}$ \\
\hline Brand loyalty & & & & & $\begin{array}{l}0.520 \\
(* * *)\end{array}$ \\
\hline Purchase intention & & & & & \\
\hline
\end{tabular}

This study examined the relationship between brand image, brand awareness, perceived quality, brand loyalty and purchase intention. Table 3 shows that brand awareness impact on perceived quality $(\beta=0.438, p<0.001)$, brand loyalty $(\beta=0.348, \mathrm{p}<0.001)$ and purchase intention $(\beta=0.285, \mathrm{p}<0.001)$. Also brand image impact on perceived quality $(\beta=0.591, \mathrm{p}<0.001)$, brand loyalty $(\beta=0.515, \mathrm{p}<0.001)$, and purchase intention $(\beta=0.351, \mathrm{p}<0.001)$. Results showed that brand image compare to brand awareness, has stronger impact on perceived quality, brand loyalty and purchase intention. In addition perceived quality impact on brand loyalty $(\beta=0.534, p<0.001)$ and purchase intention $(\beta=0.375, p<0.001)$. Finally brand loyalty impact on purchase intention $(\beta=0.520, p<0.001)$. Among all the variables, brand loyalty has stronger impact on purchase intention. Table 3 shows the data on the multiple regressions. 
Table 3. Multiple regression

\begin{tabular}{llll}
\hline Hypothesis & Standardised beta $(\mathrm{t})$ & Significant Level & Hypothesis support \\
\hline $\begin{array}{l}\text { H1:Brand awareness on perceived } \\
\text { quality }\end{array}$ & 0.438 & .000 & Supported \\
H2:Brand awareness on Brand loyalty & 0.348 & & Supported \\
H3:Brand awareness on purchase & 0.285 & .000 & Supported \\
intention & & .000 & Supported \\
H4:Brand image on & 0.591 & .000 & Supported \\
$\begin{array}{l}\text { Perceived quality } \\
\text { H5:Brand image on }\end{array}$ & 0.515 & & \\
$\begin{array}{l}\text { Brand loyalty } \\
\text { H6:Brand image on purchase intention }\end{array}$ & 0.359 & .000 & Supported \\
H7:Perceived quality on Brand loyalty & 0.534 & .000 & Supported \\
H8:Perceived quality on purchase & 0.375 & .000 & Supported \\
intention & & .000 & Supported \\
H9:Brand loyalty on & 0.520 & .000 & \\
Purchase intention & & & \\
\hline
\end{tabular}

\section{Discussion and Managerial Applications}

The findings reveal that brand awareness, brand image, perceived quality, and brand loyalty are the dimensions of brand equity. It further proved that there is a casual relationship among the dimensions of brand equity and each dimension has special affect on purchase intention of Malaysian consumers in fashion industry. Brand loyalty has stronger impact on purchase intention, subsequently followed by perceived quality, brand image and brand awareness.

The result reflects the past literature that stress on band loyalty as critical success factor to consumer purchase intention (Kandampully \& Suhartanto, 2000 and Bennett \& Rundle-Thiele, 2004). It is also discovered that compare to brand image and brand awareness; perceived quality has strongest impact on brand loyalty. This finding however does not reflect to past findings which revealed that brand image is one of the causes for attitudinal brand loyalty (Back, 2005; Flavián et al., 2006; Kandampully \& Hu, 2007). The results further prove that compare to brand awareness, brand image has stronger impact on perceived quality. As mentioned in previous literature, brand image become unique offering in highly competitive market place and the last source of differentiation (Lim \& O'Cass, 2001). This study contribute the original model of customer based brand equity developed by Aaker (1991) and recommend that brand image should be included as one of the assets to measure the brand equity.

Overall, present study confirms the casual relationship among the dimensions of brand equity and interestingly perceived quality rather than brand image has stronger impact on brand loyalty and brand loyalty rather than perceived quality has stronger impact on purchase intention. Importantly, there is no insignificant relationship among the dimensions of brand equity and thus this study provided guidelines to academicians and managers. Thus, it can be suggested that retailers should develop the effective marketing communication program that create the brand image to realize the quality of the brand. In the meanwhile, retailers should design the attractive loyalty program that motivates the customer towards purchase intention.

\section{Limitations and Future Research}

Based on the Aaker's (1996) and Keller's (1993) brand equity model, this study propose a model that explains the causal relationship among the dimensions of consumer based brand equity with purchase intention which has been neglected by most of the previous researchers. Therefore, further research is needed to explore the casual relationship among the dimensions of brand equity, which could establish a modest and stable brand equity model that can be applicable in fashion industry. Besides, the sample was limited between the ages of 18 to 40 . Further research should look into wider age group and examine the significant of the age group regarding the relationship among the dimensions of brand equity.

\section{References}

Aaker, D. A. (1996). Building Strong Brands (pp. 35-71). New York, NY: The Free Press.

Aaker, D. A., \& Keller, K. L. (1990). Consumer evaluations of brand extensions. Journal of Marketing, 54(1), 27-42. http://dx.doi.org/10.2307/1252171 
Assael, H. (1998). Consumer behavior and marketing Action (6th ed.). Cincinnati, Ohio: South-Western.

Back, K. J. (2005). The effects of image congruence on customers' brand loyalty in the upper middle-class hotel industry. Journal of Hospitality and Tourism Research, 29(4), 448-467. http://dx.doi.org/10.1177/1096348005276497

Bagozzi, R. R., Jose, C., \& Kirti, C. F. (1998). Marketing Management. Prentice Hall: Upper Saddle River.

Belch, G. E., \& Belch, M. A. (2009). Advertising and promotion: An integrated marketing communication perspective (8th ed.). New York: McGraw-Hill.

Bennet, R., \& Rundle-Thiele, S. (2004). Customer satisfaction should not be the only goal. Journal of Service Marketing, 18(7), 514-523. http://dx.doi.org/10.1108/08876040410561848

Bennet, R., \& Rundle-Thiele, S. (2005). The brand loyalty life cycle: Implications for marketers. Brand Management, 12(4), 250-263. http://dx.doi.org/10.1057/palgrave.bm.2540221

Bhuian, S. N. (1997). Marketing cues and perceived quality: Perceptions of Saudi consumers toward products of the U.S., Japan, Germany, Italy, U.K, and France. Journal of Quality Management, 2(2), 217-235. http://dx.doi.org/10.1016/S1084-8568(97)90004-3

Chadha, R., \& Husband, P. (2006). The cult of the Luxury Brand: Inside Asia's Love Affair with Luxury. London: Nicholas Brealey Publishing.

Das, B., Datta, B., \& Guin, K. (2012). From Brands in General to Retail Brands: A Review and Future Agenda for Brand Personality Measurement. The Marketing Review, 12(1), 91-106. http://dx.doi.org/10.1362/146934712X13286274424389

Deighton, J., Henderson, C. M., \& Neslin, S. A. (1994). The effects of advertising on brand switching and repeat purchasing. Journal of Marketing Research, 16, 28-43. http://dx.doi.org/10.2307/3151944

Delgad-Ballester, E., \& Munuera-Aleman, J. L. (2005). Does trust matter to brand equity? Journal of Product \& Brand Management, 14(3), 187-96. http://dx.doi.org/10.1108/10610420510601058

Delong, M., Bao, M., Wu, J., Chao, H., \& Li, M. (2004). Perception of US branded apparel in Shanghai. Journal of Fashion Marketing and Management, 8(2), 141-153. http://dx.doi.org/10.1108/13612020410537843

Dickson, M. A., Lennon, J. S., Montalto, C. P., Shen, D., \& Zhang, D. (2004). Chinese consumer market segments for foreign apparel products. The Journal of Consumer Marketing, 21(4/5), 301-315. http://dx.doi.org/10.1108/07363760410549131

Engel, J., Roger, B., \& Paul, M. (1995). Consumer Behavior Forth Worth. The Dryden Press.

Fishbein, M., \& Icek, A. (1975). Belief, Attitude, Intention, and Behavior: An Introduction to Theory and Research. Reading, MA: Addison-Wesley.

Flavián, C., Guinalíu, M., \& Gurrea, R. (2006). The role played by perceived usability, satisfaction and consumer trust on website loyalty. Information and Management, 43(1), 1. http://dx.doi.org/10.1016/j.im.2005.01.002

Grewal, D., Monroe, K. B., \& Krishnan, R. (1998). The effects of price-comparison advertising on buyers' perceptions of acquisition value, transaction value and behavioral intentions. Journal of Marketing, 62(2), 46-59. http://dx.doi.org/10.2307/1252160

Heding, T., Knudtzen, C. F., \& Bjerre, M. (2009). Brand management research, theory and practice (1st ed.). Routledge, 270 Madison Ace, New York, NY.

Jones, M. A., Mothersbaugh, D. L., \& Beatty, S. E. (2002). Why customers stay: measuring the underlying dimensions of services switching costs and managing their differential strategic outcomes. Journal of Business Research, 55(6), 441-450. http://dx.doi.org/10.1016/S0148-2963(00)00168-5

Kandampully, J., \& Hu, H. (2007). Do hoteliers need to manage image to retain loyal customer. International Journal of Contemporary Hospitality Management, 19(6), 435-443. http://dx.doi.org/10.1108/09596110010342559

Kandampully, J., \& Suhartanto, D. (2000). Customer loyalty in the hotel industry: The role of customer satisfaction and image. International Journal of Contemporary Hospitality Management, 12(6), 346-351. http://dx.doi.org/10.1108/09596110710775101

Kaplan, M. D. (2007). Product Appearance and Brand Knowledge: An Analysis of Imperative Relationships. Unpublished doctoral dissertation, Izmir University of Economics. 
Keller, K. L. (1993). Conceptualizing, measuring, and managing customer-based brand equity. Journal of Marketing, 57(1), 1-22. http://dx.doi.org/10.2307/1252054

Keller, K. L. (1998). Strategic brand management: Building, measuring and managing brand equity. London: Prentice Hall International.

Keller, K. L. (2003). Building, measuring, and managing brand equity. New Jersey: Pearson Education.

Keller, K. L., \& Donald, R. L. (2003). How do brands create value? Marketing Management.

Kim, K. (2008). Brand Equity in Hospital Marketing. Journal of Business Research, 61, 755-782. http://dx.doi.org/10.1016/j.jbusres.2006.05.010

Kimery, K. M., \& McCord, M. (2002). iThird-party assurances: the road to trust in online retailing, Conference Proceedings of the 35nd Hawaii, International Conference on System Sciences, 2002.

Kotler, P., \& Keller, K. L. (2009). Marketing Management (13th ed.). Pearson Education, Upper Saddle River, NJ

Lassar, W., Mittal B., \& Sharma A. (1995). Measuring Customer-Based Brand Equity. Journal of Consumer Marketing, 12(4), 11-19. http://dx.doi.org/10.1108/07363769510095270

Lim, K., \& O'Cass, A. (2001). Consumer Brand Classifications: An assessment of Culture-of-Origin versus Country-of-Origin. Journal of Product and Brand Management, 10(2), 120-136. http://dx.doi.org/10.1108/10610420110388672

Lin, S. Y. (2006). The impact of warranty and brand awareness on customer loyalty. Chinese Management Review, $8(1), 1-20$.

Macdonald, E. K., \& Sharp, B. M. (2000). Brand awareness effects on consumer decision making for a common, repeat purchase product: A replication. Journal of Business Research, 48(1), 5-15. http://dx.doi.org/10.1016/S0148-2963(98)00070-8

Oliver, R. L. (1999). Whence Consumer Loyalty? Journal of Marketing, 63, 33-44. http://dx.doi.org/10.2307/1252099

Oliver, R., \& Rust, R. (1997). Customer Delight: Foundations, Findings, and Managerial Insight. Journal of Retailing, 73(3). http://dx.doi.org/10.1016/S0022-4359(97)90021-X

Parasuraman, A., \& Grewal, D. (2000). The impact of technology on the quality-value-loyalty chain: A research agenda. Journal of the Academy of Marketing Science, 28(1), 168-174. http://dx.doi.org/10.1177/0092070300281015

Percy, L., \& Rossiter, J. R. (1992). A model of brand awareness and brand attitude advertising strategies. Psychology \& Marketing, 9, 263-274. http://dx.doi.org/10.1002/mar.4220090402

Rao, A. R., \& Monroe, K. B. (1989). The effect of price, brand name, and store name on buyers' perceptions of product quality: An integrative review. Journal of Marketing Research, 26, 351. http://dx.doi.org/10.2307/3172907

Richards, L., Foster, D., \& Morgan, R. (1998). Brand Knowledge Management: Growing Brand Equity. Journal of Knowledge Management, 2(1), 47-54. http://dx.doi.org/10.1108/13673279810800762

Schiffman, L. G., \& Kanuk, L. L. (2000). Consumer Behavior (7th ed.). Wisconsin: Prentice Hall

Sidek, Yee, A. F., \& Yahyah, B. (2008). Influence of Brand Loyalty on Consumer Sportswear. International Journal of Economics and Management.

Soureli, M., Lewis, B. R., \& Karantinou, K. M. (2008). Factors that affect consumers' cross buying intention: A model for financial services. Journal of Financial Service Marketing, 13(1), 5-16. http://dx.doi.org/10.1057/fsm.2008.1

Wang, C. C., \& Hwang, I. S. (2001). The Influence of Product Knowledge on the Amount of Merchandises Information Search on Internet. Journal of Business Administration, 51, 109-138.

Wu, L. M. (2007). The study of the brand image, perceived quality, brand loyalty and repurchase intention.

Yang, Y. T. (2009). A study of purchase intention behavior to consumers on innovation technology smart phone in technology acceptance model and theory of reason action. Unpublished master thesis, Nan Hua University, Taiwan.

Yasin, N. M., Nasser, N., \& Mohamad, O. (2007). Does image of country-of-origin matter to brand equity. Journal of Product \& Brand Management, 16(1), 38-48. http://dx.doi.org/10.1108/10610420710731142 
Yee, F. W., \& Sidek, Y. (2008). Influence of Brand Loyalty on Consumer Sportswear. International Journal of Economic and Management, 2(2), 221-236.

Yoo, B., Donthu, N., \& Lee, S. (2000). An examination of selected marketing mix elements and brand equity. Journal of the Academy of Marketing Science, 28(2), 195-211. http://dx.doi.org/10.1177/0092070300282002

Zeithaml, V. A. (1988). Consumer perceptions of price, quality, and value: A means-end model and synthesis of evidence. Journal of Marketing, 52, 2-22. http://dx.doi.org/10.2307/1251446

\section{Appendix}

Measurement items for brand awareness

\begin{tabular}{lll}
\hline Instructs & Coding & Items \\
\hline & BA1 & Some characteristics of Brand X come to my mind quickly. \\
& BA2 & I can recognize Brand X quickly among other competing brands. \\
Brand Awareness & BA 3 & I have seen different advertisements for Brand X in TV, Magazine, \\
& BA 4 & Newspaper, Internet and etc. \\
& BA 5 & I am familiar with Brand X. \\
& I can quickly recall the symbol or logo of the Brand X \\
\hline
\end{tabular}

Measurement items for brand image

\begin{tabular}{lll}
\hline Instructs & Coding & Items \\
\hline & BI1 & Brand X performs as expected. \\
Brand image & BI 3 & Brand Name and Image attract me to purchase \\
& BI4 & Brand X expresses my personality. \\
& BI5 & Brand X targets high-income level. \\
& BI6 & Brand X increases the respectability of a user \\
\hline
\end{tabular}

Measurement items for perceived quality

\begin{tabular}{lll}
\hline Instructs & Coding & Items \\
\hline & PQ1 & The Brand has good functional quality.. \\
& PQ2 & The materials used by the Brand are comfortable \\
Perceived quality & PQ 3 & The Brand has sufficient color. \\
& PQ4 & The Brand X is durable to use \\
& PQ5 & The Brand provides wide variety of styles \\
& PQ6 & Styles of the Brand are trendy and fashionable. \\
\hline
\end{tabular}

Measurement items for Brand Loyalty

\begin{tabular}{lll}
\hline Instructs & Coding & Items \\
\hline & BL1 & Brand X offers good value for price \\
& BL2 & Increases of price not hinder me to purchase \\
Brand Loyalty & BL 3 & I usually use Brand X as my first choice compared to other Brands. \\
& BL4 & I am satisfied with this Brand. \\
& BL5 & I would recommend Brand X to others. \\
& BL6 & I would not switch to another Brand. \\
& BL7 & I can always trust Brand X. \\
\hline
\end{tabular}

Measurement items for Purchase Intention

\begin{tabular}{lll}
\hline Instructs & Coding & Items \\
\hline \multirow{4}{*}{ Purchase intention } & PI1 & I will buy from this brand in the near future. \\
& PI2 & I would consider buying from this brand in the future. \\
& PI3 & I have intention to buy this brand in the future. \\
\hline
\end{tabular}




\section{Copyrights}

Copyright for this article is retained by the author(s), with first publication rights granted to the journal.

This is an open-access article distributed under the terms and conditions of the Creative Commons Attribution license (http://creativecommons.org/licenses/by/3.0/). 